\title{
Lateral
}

Journal of the Cultural Studies Association

\section{Review of Infrastructures of Apocalypse: American Literature and the Nuclear Complex by Jessica Hurley (University of Minnesota Press)}

\author{
by Douglas Dowland | Book Reviews, Issue 10.2 (Fall 2021) \\ ABSTRACT Jessica Hurley's Infrastructures of Apocalypse: American Literature \\ and the Nuclear Complex examines how postwar literature has responded to \\ discourses, both official and unofficial, of nuclear weaponry and nuclear power. \\ Hurley explores how literature from a variety of genres offer a different sense of past, \\ present, and future in response, thus constructing the apocalypse as a \\ transfiguration rather than as a revelation.
}

KEYWORDS apocalypse, narrative, literature, nuclear, containment

Infrastructures of Apocalypse: American Literature and the Nuclear Complex. By Jessica Hurley. Minneapolis: University of Minnesota Press, 2020. 294 pp.

(paperback) ISBN: 978-1-5179-0874-4. US List: \$27.00.

The discourse of the nuclear is rife with arrogance: we think we can control it; and we think that if we cannot control it, what comes after is something that we will somehow (want to) survive. Jessica Hurley thoroughly challenges this arrogance throughout Infrastructures of Apocalypse, revealing how the assumptions of the American nuclear regime, from its sense of time and space to their sense of what constitutes the human, is a web of discourse that is often under contestation by a gamut of writers. These writers envision apocalypses that are neither ending nor revelation. Instead, they "use apocalypse to transfigure the present: to see the other possibilities that reside in it . . constructing only a transfigured instant but wholly transfigured timelines" (4). In doing so, their narratives capture a present that is as un-survivable as the postapocalyptic nuclear future, a present that is not sustainable without imagining it otherwise.

Hurley's first chapter, "White Sovereignty and the Nuclear State," offers an insightful reading of Ayn Rand's Atlas Shrugged. Drawing on discourses of Orientalism, Hurley sees at work in Rand's writing the threat of totalitarianism encoded as the threat of becoming "Oriental": in this way, Rand draws upon an unfortunate heritage of "yellow peril" discourse that demonstrates "the centrality of race to her conception of personhood" (54). Hurley's deft reading of Rand's erratic tome for its depiction and description of "Orientals" works 
well to show how Rand employs the nuclear apocalypse as one in which only the (white, entrepreneurial) elite will survive to take on their roles as frontiersman in a land ruined by a despotism-inducing welfare state. This sort of white fantasy-making returns (sadly, unsurprisingly) in Hurley's chapter on the 1980s: both chapters reveal how some see the apocalypse not as a horror but as the ultimate success of white privilege.

Chapter Two, "Civil Defense and Black Apocalypse," is a study of James Baldwin's Tell Me How Long the Train's Been Gone and Samuel Delany's Dhalgren. Here, Hurley's focus is on how these novels' characters "find themselves lost, wandering in memory and in cities that cannot be read, scrolled environments that operate under lawless grammars" (76). Whereas Baldwin's book is a "fictional attempt to reckon with the disappointment" that white America is more than willing to disinvest itself of equality in the name of its own sustenance, Delany's book reveals the "essential conservatism" (98) of plots of racial unity, exposing how "the future can only appear within the terms set by the past" (118). Baldwin's disappointment is thus a lost faith in the traditional sense of the apocalypse bringing about redemption: Delany's playing with time (and space) in Dhalgren disconnects totally the glue between events that gives the present any sense of having a past and a future.

Hurley shows us through her third chapter, "Star Wars, AIDS, and Queer Endings," a way to critique the resurgence of the nuclear apocalypse during the Reagan administration. She reminds us how the "insistent backward connection between the 1980s and the 1950s that allows neoconservative America to imagine itself as safe through a retroactive temporality" performs a type of "retrocontainment" (125). Reagan's "Star Wars" project comes with a 1980s promise, perhaps achieved for a sliver of time in the late 1940s, that the US could have supremacy over nuclear weapons, a new version of "a past where America was secure in its nuclear superiority" (131). Tony Kushner's Angels subverts this in its use of characters from the past who live out alternative futures: uncannily, it "makes us aware of our own existence as 'future dead people,"' a chilling reminder that containment, current or retro, is always a fiction (149).

The fourth chapter, "Nuclear Waste, Native America, Narrative Form," reads David Foster Wallace's Infinite Jest alongside Leslie Marmon Silko's Almanac of the Dead. Together, Hurley shows how they remind us that "the US nuclear complex has been a colonial project" from its inception (178). Wallace's "Concavity/Convexity Zone" or the stone snake that emerges in Silko's novel work as figures to how "the Euro-American temporality of cause and effect" ruin the landscape and individual lives, how our relationship to nuclear waste extends far beyond ourselves and our conception of time and space (187). Each reminds us that the nuclear regime comes with a longue durée that is ultimately truly unfathomable, an apocalypse that is neither distant nor fast but present and plodding. It is a future that we are living, incommensurably, now.

Hurley's reading of the postwar and the postmodern is particularly effective in the nontraditional examples she offers at the beginning of each chapter, whether they be memoranda from the head of the Atomic Energy Commission, the chillingly racist imagery used by the Federal Civil Defense Administration, the haunting reminder that atomic tests on US soil were often named after Native American tribes, or the bureaucratically mundane 
discourse surrounding Waste Isolation Pilot Plant (WIPP), a deep geological depository in New Mexico. I particularly enjoyed Hurley's reading of Ruth Ozeki's A Tale for the Time Being alongside the Fukushima Daiichi disaster that serves as the book's coda.

Nuclear waste is "our own self-created predator," Hurley writes (202). As her book brings to our attention, it is a predator we have created, complete with an infrastructure that justifies its presence in the present. A predator we foolishly think that we can control, it shows what we are willing to deprive future generations of: an uncontaminated planet, a more equal society, and the fascinating narratives that would come from it.

\section{Author Information}

\section{Douglas Dowland}

Douglas Dowland is Associate Professor of English at Ohio Northern University and the author of Weak Nationalisms: Affect and Nonfiction in Postwar America (University of Nebraska Press, 2019).

View all of Douglas Dowland's articles.

\section{Article details}

Douglas Dowland, "Review of Infrastructures of Apocalypse: American Literature and the Nuclear Complex by Jessica Hurley (University of Minnesota Press)," Lateral 10.2 (2021).

https://doi.org/10.25158/L10.2.25

This article is licensed under a Creative Commons Attribution-NonCommercial 4.0 International License. Copyright is retained by authors.

Lateral is the peer-reviewed, open access journal of the Cultural Studies Association.

ISSN 2469-4053 